\title{
Effect of Organic Fertilization on Growth and Development of the Root System of two Medicinal Plants, oregano (Origanum vulgare L.) and milk thistle (Silybum marianum L. Gaertn.)
}

\author{
Foteini ANGELOPOULOU ${ }^{1)}$, Ioanna KAKABOUKI ${ }^{2)}$, Panagiota PAPASTYLIANOU ${ }^{1)}$, Yolanda PAPATHEO- \\ HARI $^{1}$, Aristidis KONSTANTAS ${ }^{1}$, Anestis KARKANIS ${ }^{3)}$, Ilias TRAVLOS ${ }^{1)}$ and Dimitrios J. BILALIS ${ }^{1^{*}}$ \\ ${ }^{1)}$ Agriculture University of Athens, Department of Crop Production, Iera Odos 75, 11855 Athens, \\ Greece. \\ 2) University of West Greece, Department of Business Administration of Food and Agricultural Enter- \\ prises, Seferi 2, 30100, Agrinio, Greece. \\ 3) Department of Agriculture Crop Production and Rural Environment, University of Thessaly, Fytokou \\ Str, 38446, Nea Ionia, Magnesia, Greece. \\ ${ }^{*}$ Coresponding author, e-mail: bilalisdimitrios@yahoo.gr.
}

Bulletin UASVM Horticulture 71(2) / 2014

Print ISSN 1843-5254, Electronic ISSN 1843-5394

DOI:10.15835/buasvmcn-hort:10412

\begin{abstract}
Field experiment was conducted in western Greece to determine the effects of organic fertilization on root growth of medicinal plants oregano (Origanum vulgare L.) and milk thistle (Silybum marianum L. Gaertn.). The experimental design was completely randomized with four replications. Two treatments were applied; compost $2000 \mathrm{~kg} \mathrm{ha}^{-1}$ (F1) and compost $4000 \mathrm{~kg} \mathrm{ha}^{-1}$ (F2). The results indicated that the soil properties were influenced by organic fertilization. The highest organic matter and total nitrogen content were found under F2 treatment. Also, F2 treatment improves soil porosity. Moreover, there were significant differences in root growth between fertilization treatments. For both medicinal plants the highest root length density, root mass density and root surface density were found under F2 treatment. Furthermore, there were significant differences in arbuscular mycorrhizal (AMF) root colonization between fertilization treatments. The greatest values were observed for F2 treatment. The highest AMF root colonization was found for oregano. A positive correlation was found between AMF root colonization and root surface density. Our results indicated that oregano and milk thistle root growth was improved with increasing compost application rates.
\end{abstract}

Keywords: medicinal plants, Origanum vulgare, organic fertilization, Silybum marianum.

\section{INTRODUCTION}

Oregano (Origanum vulgare L.) and milk thistle (Silybum marianum L. Gaertn) are widely used as medicinal plants and both are native to the Mediterranean basin. In Greece, milk thistle it is considered a weed, in its native range, and is found on roadsides and waste ground, and in cereal crops (Karkanis et al., 2011). The main active constituent of milk thistle seeds is silymarin. Silymarin is used widely in the treatment of liver diseases (Abenavoli et al., 2010). Oregano crop is important for farmers since it brings in significant income. The main component of oregano essential oils is carvacrol (Olmedo et al., 2014). Oregano plants are known to show antifungal, antioxidant, antibacterial and antimicrobial activities (Vitoratos et al., 2013; Chishti et al., 2013).

Medicinal and aromatic plants respond well to inorganic and organic fertilization. Singh et al. (2014) reported that the combined application of $50 \%$ of inorganic fertilizers and farmyard manure increase the essential oil yield of basil (Ocimum basilicum). In coriander crop, Carrubba (2014) reported that some beneficial effect on yields was 
observed after the application of certain organic $\mathrm{N}$ fertilizers containing significant amounts of $\mathrm{P}$. There are few references to organic oregano and milk thistle in the literature (Khalil et al., 2007; Kouřimská et al., 2014). Kouřimská et al. (2014) observed that there were no significant differences between the organic and conventional farming for oregano (Origanum vulgare L. and Origanum heracleoticum) and spearmint (Mentha spicata L.) antioxidant activity.

The objective of this study was to evaluate the effect of two levels of organic fertilization in the development and characteristics of the root system of medicinal plants Origanum vulgare and Silybum marianum.

\section{MATERIALS AND METHODS}

Field experiment was carried out in western Greece in the region of city Agrinio (38 $38^{\prime} 08.43^{\prime \prime}$, $\left.21^{\circ} 21^{\prime} 16.62^{\prime \prime}\right)$ in 2013. It was established in the 'organic' experimental field of ASKAFEFA cooperative union and certificated by TUV Austria (EN 834/2007). The soil was a clay loam $(24.9 \%$ clay, $61.2 \%$ silt, and $13.9 \%$ sand) with $\mathrm{pH} 7.6$ and EC $0.63 \mathrm{mS} \mathrm{cm} \mathrm{cm}^{-1}$. Oregano seedlings were transplanted at the beginning of June 2013 in rows of $75 \mathrm{~cm}$ apart. Transplants were set at $35 \mathrm{~cm}$ between each other. Milk thistle was sown at the beginning of December 2013 by hand and row spacing was $75 \mathrm{~cm}$, with $50 \mathrm{~cm}$ between plants in the row.

The experimental design was completeley randomized with four replications. Each organic fertilization had two levels (normal and double dose). Compost, consisting of a mixture of farmyard manure and medicinal plants residues, applied at a rate of $2000 \mathrm{~kg} \mathrm{ha}^{-1}$ for the normal fertilization dose (F1) and for the double fertilization dose $4000 \mathrm{~kg} \mathrm{ha}^{-1}$ (F2). The plot size was $24 \mathrm{~m}^{2}$ (3m x $8 \mathrm{~m})$. Weeds were controlled by hand, with two hoeing's being carried out. The composition of applied compost was N-total 6\%, P-olsen $7 \%, \mathrm{~K}$ $9 \%, \mathrm{Mg} 2 \%$ and $\mathrm{pH} 7.2$.

The parameters that were determined were: root length density (RLD), root mass density (RMD), root surface density (RSD), arbscular mycorrhiza (AMF), soil porosity (SP) , soil organic matter and soil N-total. Root samples were collected from the $0-35 \mathrm{~cm}$ layer by using a cylindrical auger $(25 \mathrm{~cm}$ length, $10 \mathrm{~cm}$ diameter) at the midpoint between successive plants within a row. Root measurements were made at the beginning of July 2014, at flowering stage and at maturity stage for oregano and milk thistle, respectively. Firstly, roots were separated from the soil by soaking the samples overnight in $30 \mathrm{ml}$ of a $0.5 \%$ solution of sodium hexametaphosphate. Afterwards, the samples were stirred for $5 \mathrm{~min}$ and washed over a $5 \mathrm{~mm}$ mesh-sieve. The roots thus held on the sieves were decanted into a $0.1 \%$ trypan blue FAA staining solution (mixture of $10 \%$ formalin, $50 \%$ ethanol and 5\% acetic acid solutions). For the determination of root length density (RLD) and root surface (RS), the stained root samples were placed on a high resolution scanner (Hewlett Packard 4c, Palo Alto, CA, USA) and images captured using Delta-T software was used, (Delta-T Scan version 2.04; Delta-T Devices Ltd, Burwell, Cambridge, UK). The root dry mass density (RMD) was determined after drying for 48 h at $70{ }^{\circ} \mathrm{C}$.

The second root samples were cleaned and stained with trypan blue in lactophenol, according to the method of Phillips and Hayman (1970). The percentage of root length colonized by AM fungi was determined microscopically with the gridlineintersection method at a magnification of $\times 30-40$ (Giovannetti and Mosse, 1980). Total porosity of the soil was determined by $1-\mathrm{Db} / \mathrm{Dp}$, where $\mathrm{Dp}$ is the particle density $\left(2.5 \mathrm{~g} \mathrm{~cm}^{-3}\right)$ and $\mathrm{D}_{\mathrm{b}}$ is the soil bulk density. Soil bulk density was determined for each plot by taking undisturbed soil cores with $100 \mathrm{~cm}^{3}$-cylinders from a depth of $0-10 \mathrm{~cm}$. The Wakley and Black method (1934) was used to determine the soil organic matter content. The soil $\mathrm{N}$-total determined by Kjeldahl Method (Bremner, 1960).

For analysis of variance (ANOVA), comparisons of means and 3D graphs, the software Statsoft (2007), was used. All comparisons were made at the $5 \%$ level of significance.

\section{RESULTS AND DISCUSSION}

Organic fertilization influences the soil properties. The highest organic matter and soil total nitrogen were obtained with double rate compost (F2) treatment (Tab. 1). According to Efthimiadou et al. (2010) organic matter content was proportionate to the amount of manure applied. Furthermore, the highest soil porosity was found under double rate compost (F2) treatment. The addition of organic materials (i.e. 
Tab. 1. Effect of organic fertilization (F1: compost $2000 \mathrm{~kg} \mathrm{ha}^{-1}$ and F2: compost $4000 \mathrm{~kg} \mathrm{ha}^{-1}$ ) on soil quality and root properties of oregano and milk thistle plants. F values and p-levels are also shown.

\begin{tabular}{|c|c|c|c|c|c|c|c|}
\hline Oregano crop & $\begin{array}{c}\text { Soil } \\
\text { Porosity } \\
\%\end{array}$ & $\begin{array}{l}\text { Soil N } \\
\text { total }\end{array}$ & $\begin{array}{l}\text { Organic } \\
\text { Matter }\end{array}$ & $\begin{array}{l}\mathrm{RMD} \mathrm{g} / \\
\mathrm{cm}^{3}\end{array}$ & $\begin{array}{c}\mathrm{RLD} \mathrm{cm} / \\
\mathrm{cm}^{3}\end{array}$ & $\begin{array}{c}\mathrm{RSD} \mathrm{mm} \\
\mathrm{cm}^{3}\end{array}$ & AMF \% \\
\hline $\mathrm{F} 1$ & 41.25 & 0.185 & 1.800 & 0.135 & 0.341 & 1.071 & 46.25 \\
\hline $\mathrm{F} 2$ & 43.75 & 0.217 & 2.058 & 0.171 & 0.442 & 1.388 & 54.50 \\
\hline F value & 6.52 & 11.80 & 11.54 & 15.56 & 2.70 & 52,86 & 14.14 \\
\hline p level & 0.043 & 0.014 & 0.015 & 0.008 & 0.151 & 0.0003 & 0.009 \\
\hline Milk thistle crop & $\begin{array}{c}\text { Soil } \\
\text { Porosity } \\
\%\end{array}$ & $\begin{array}{c}\text { Soil N } \\
\text { total }\end{array}$ & $\begin{array}{l}\text { Organic } \\
\text { Matter }\end{array}$ & $\begin{array}{l}\mathrm{RMD} \mathrm{g} / \\
\mathrm{cm}^{3}\end{array}$ & $\begin{array}{c}\mathrm{RLD} \mathrm{cm} / \\
\mathrm{cm}^{3}\end{array}$ & $\begin{array}{c}\mathrm{RSD} \mathrm{mm^{2 }} / \\
\mathrm{cm}^{3}\end{array}$ & AMF \% \\
\hline $\mathrm{F} 1$ & 40.50 & 0.140 & 1.449 & 0.232 & 0.873 & 0.637 & 32.75 \\
\hline $\mathrm{F} 2$ & 44.00 & 0.197 & 1.818 & 0.293 & 1.064 & 0.901 & 37.00 \\
\hline $\mathrm{F}$ value & 5.44 & 9.03 & 27.93 & 3.22 & 16.02 & 17.90 & 11.56 \\
\hline p level & 0.058 & 0.024 & 0.002 & 0.123 & 0.007 & 0.005 & 0.014 \\
\hline
\end{tabular}

compost, manure) to agricultural soils improves soil properties and health (Brown and Cotton, 2011; Celik et al., 2004). Mylavarapu and Zinati (2009) also reported that the addition of compost resulted in improvement of both soil physical and chemical properties. Celik et al. (2004) observed that compost and manure treatments increased available water content of soils by 86 and 56\%, respectively. Moreover, composts from aromatic plant wastes can be used to enhance the soil microbial activity (Kayikcioglu, 2013).

Compost application improves soil quality and also the crop growth and yield. For both medicinal plants, there were significant differences in root growth between compost treatments (Tab. 1). Oregano responds well to organic fertilization. Corrêa et al. (2010) found that cattle and chicken manure significantly influenced oregano plant growth. Our results indicated that the highest oregano root mass density and root length density was observed for double rate compost treatment $\left(0.171 \mathrm{~g} / \mathrm{cm}^{3}\right.$ and $0.441 \mathrm{~cm} / \mathrm{cm}^{3}$, respectively). Mbatha et al. (2014) also reported that as organic fertiliser rate increased, parsley root fresh mass increased.

Moreover, in milk thistle crop, the highest root mass density and root length density were again found in F2 treatment $\left(0.293 \mathrm{~g} / \mathrm{cm}^{3}\right.$ and 1.064 $\mathrm{cm} / \mathrm{cm}^{3}$, respectively). Moreover, the root length density was lower in oregano crop than that in milk thistle crop. In addition, the root surface density was higher in oregano crop than that in milk thistle crop. According to Zhang et al. (2014) the compost application increases rhizosphere soil carbon mineralization and stimulates root growth in cucumber crop. The root surface density had positive and significant correlation (Tab. 2) with soil nitrogen total ( $\mathrm{r}=0.797, \mathrm{p}<0.05$ and $r=0.971, p<0.001$, for oregano and milk thistle crop, respectively). Sotiropoulou and Karamanos (2010) found that oregano root surface density in the top $25 \mathrm{~cm}$ of soil was positively affected by nitrogen. Moreover, root surface density had positive and significant correlation with organic matter content in soil $(\mathrm{r}=0.796, \mathrm{p}<0.05$ and $r=0.789, p<0.05$, for oregano and milk thistle crop, respectively).

Furthermore, in oregano crop, the multiple regression analysis indicates that there is statistically significant relationship between root surface density, soil $\mathrm{N}$ total and soil organic matter as described by the equation given in Fig. 1. Similarly, in milk thistle crop (Fig. 2), multiple regression analysis between root surface density soil $\mathrm{N}$ total and soil organic matter was also significant. The R-squared statistic indicates that 
Tab. 2. Correlations coefficients ${ }^{1}$ between soil properties and root parameters of oregano (Origanum vulgare L.) and milk thistle (Silybum marianum L. Gaertn).

\begin{tabular}{|c|c|c|c|c|c|c|c|}
\hline Oregano Crop & $\begin{array}{c}\text { Soil } \\
\text { Porosity }\end{array}$ & Soil $\mathrm{N}$ total & $\begin{array}{l}\text { Organic } \\
\text { matter }\end{array}$ & RMD & RLD & RSD & AMF \\
\hline Soil Porosity & - & - & - & - & - & - & - \\
\hline Soil N total & $0.413 \mathrm{~ns}$ & - & - & - & - & - & - \\
\hline Organic matter & $0.836^{* *}$ & $0.458 \mathrm{~ns}$ & - & - & - & - & - \\
\hline RMD & $0.670 \mathrm{~ns}$ & $0.890^{* *}$ & $0.665 \mathrm{~ns}$ & - & - & - & - \\
\hline RLD & $0.589 \mathrm{~ns}$ & $0.431 \mathrm{~ns}$ & $0.413 \mathrm{~ns}$ & $0.632 \mathrm{~ns}$ & - & - & - \\
\hline RSD & $0.6481 \mathrm{~ns}$ & $0.797^{*}$ & $0.796^{*}$ & $0.858^{* *}$ & $0.534 \mathrm{~ns}$ & - & - \\
\hline AMF & $0.813^{* *}$ & $0.665 \mathrm{~ns}$ & $0.896^{* *}$ & $0.747^{*}$ & $0.471 \mathrm{~ns}$ & $0.763^{*}$ & - \\
\hline Milk thistle crop & $\begin{array}{c}\text { Soil } \\
\text { Porosity }\end{array}$ & Soil $\mathrm{N}$ total & $\begin{array}{l}\text { Organic } \\
\text { matter }\end{array}$ & RMD & RLD & RSD & AMF \\
\hline Soil Porosity & - & - & - & - & - & - & - \\
\hline Soil N total & $0.756^{*}$ & - & - & - & - & - & - \\
\hline Organic matter & $0.670 \mathrm{~ns}$ & $0.707^{*}$ & - & - & - & - & - \\
\hline RMD & $0.561 \mathrm{~ns}$ & $0.526 \mathrm{~ns}$ & $0.537 \mathrm{~ns}$ & - & - & - & - \\
\hline RLD & $0.788^{*}$ & $0.749^{*}$ & $0.647 \mathrm{~ns}$ & $0.357 \mathrm{~ns}$ & - & - & - \\
\hline RSD & $0.680 \mathrm{~ns}$ & $0.971^{* * *}$ & $0.789^{*}$ & $0.559 \mathrm{~ns}$ & $0.755^{*}$ & - & - \\
\hline AMF & $0.870^{* *}$ & $0.733^{*}$ & $0.604 \mathrm{~ns}$ & $0.560 \mathrm{~ns}$ & $0.948^{* * *}$ & $0.725^{*}$ & - \\
\hline
\end{tabular}

${ }^{1} \mathrm{r}$ was calculated using the linear equation. Significant at ${ }^{*} \mathrm{P}=0.05,{ }^{* *} \mathrm{P}=0.01$ and ${ }^{* * *} \mathrm{P}=0.001$, respectively. ns: not significant.

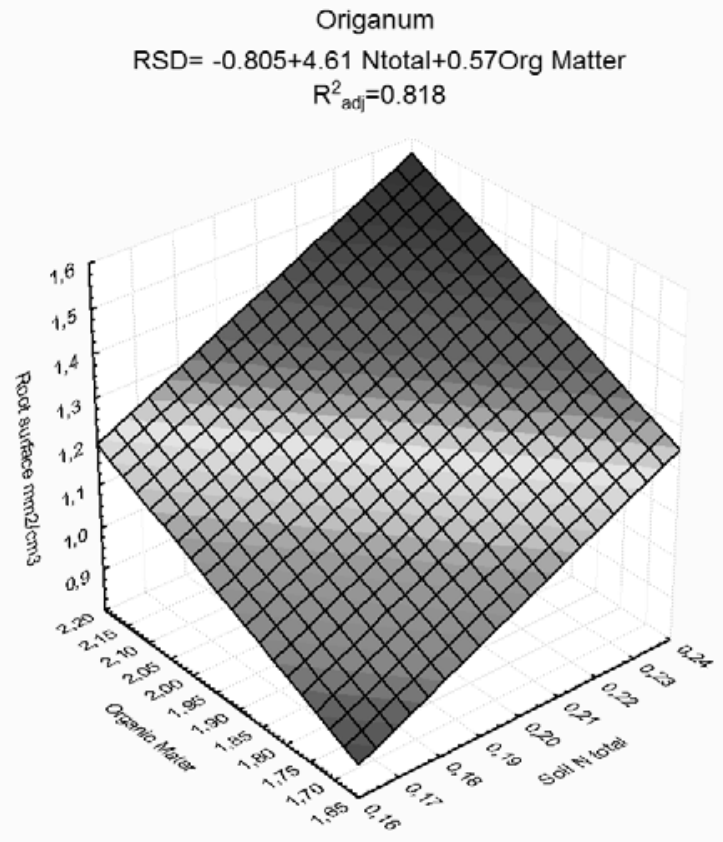

Fig. 1. Multiple regression analysis between root surface density (RSD) of oregano crop, soil organic matter and soil $\mathrm{N}$ total. 


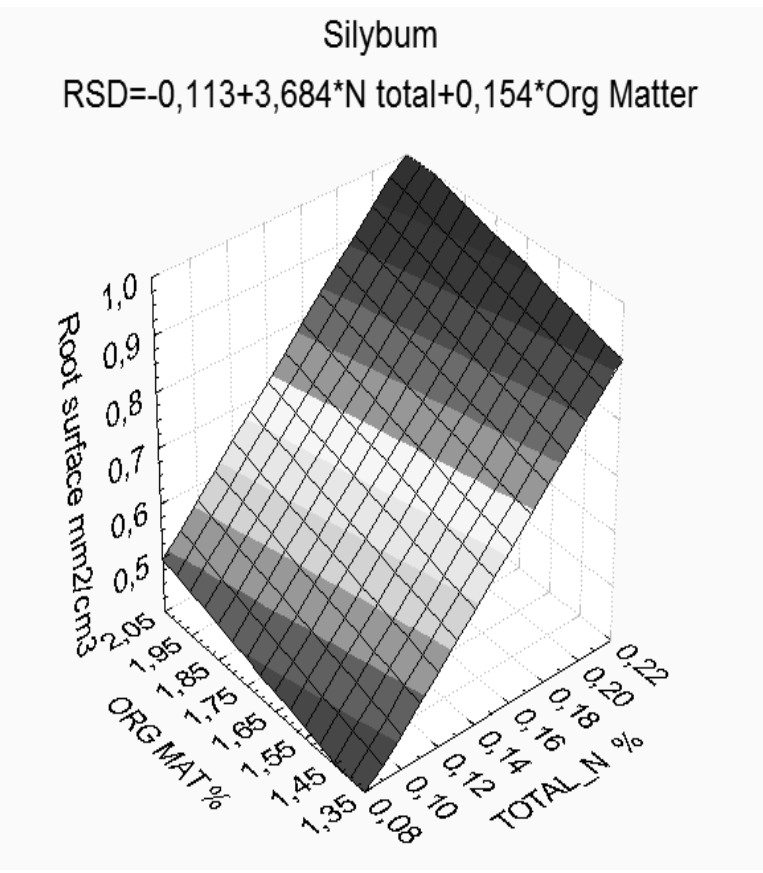

Fig. 2. Multiple regression analysis between root surface density (RSD) of milk thistle crop, soil organic matter and soil $\mathrm{N}$ total.

the two models explain the variability in root surface density of oregano and milk thistle crop by $81 \%$ and $95 \%$, respectively.

Concerning the AMF root colonization (Tab. 2) of oregano and milk thistle plants, there were significant differences between the compost treatments. The highest AMF root colonization was found under the double rate compost treatment (54.50\% and $37 \%$ for oregano and milk thistle plants). Khaosaad et al. (2006) also observed that oregano plants were well colonized. Cavagnaro (2014) observed that while the compost addition at low rates of application had little effect on root colonization by $\mathrm{AM}$, at higher rates a small decrease in colonization of roots by AMF was observed. The AMF root colonization was lower in milk thistle crop than that in oregano crop. The AMF root colonization had positive and significant correlation (Tab. 2) with root surface density ( $r=0.763, p<0.05$ and $r=0.725, p<0.05$, for oregano and milk thistle crop, respectively). Moreover, AMF root colonization had positive and significant correlation with soil porosity $(\mathrm{r}=0.813, \mathrm{p}<0.01$ and $\mathrm{r}=0.870, \mathrm{p}<0.01$, for oregano and milk thistle crop, respectively).

\section{CONCLUSION}

Our results indicated that the soil properties were influenced by organic fertilization. The highest organic matter and total nitrogen content were found with double compost treatment. Moreover, there were significant differences in root growth between fertilization treatments. For both medicinal plants the highest root length density, root mass density and root surface density were found under F2 treatment. Furthermore, the highest values of AMF root colonization were observed for F2 treatment. The AMF root colonization was lower in milk thistle crop than that in oregano crop. Our results indicated that the compost at high rate improve oregano and milk thistle root growth.

Acknowledgements. The project supported by EU \& Greek General Secretary of Research \& Technology, Program Synergasia - ENGAGE.

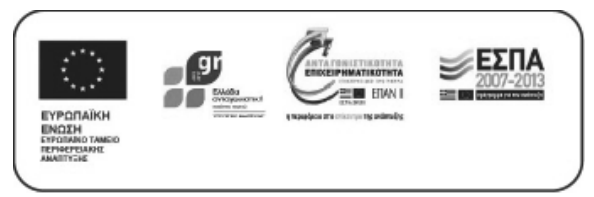




\section{REFERENCES}

1. Abenavoli L, Capasso R, Milic N, Capasso F (2010). Milk thistle in liver diseases: past, present, future. Phytother Res 24(10): 1423-1432.

2. Bremner JM (1960). Determination of nitrogen in soil by Kjedahl method. J Agric Sci 55:11-33.

3. Brown S, Cotton M (2011). Changes in soil properties and carbon content following compost application: Results of on-farm sampling. Compost Sci Util 19: 87-96.

4. Carrubba A (2014). Organic and chemical fertilization on coriander (Coriandrum sativum L.) in a Mediterranean environment. Ind Crops Prod 57: 174-187.

5. Cavagnaro TR (2014). Impacts of compost application on the formation and functioning of arbuscular mycorrhizas. Soil Biol Biochem 78: 38-44.

6. Celik I, Ortas I, Kilic S (2004). Effects of compost, mycorrhiza, manure and fertilizer on some physical properties of a Chromoxerert soil. Soil Tillage Res 78: 5967.

7. Chishti S, Kaloo ZA, Sultan P (2013). Medicinal importance of genus Origanum: A review J Pharmacogn Phytother 5(10): 170-177.

8. Corrêa RM, Pinto JEBP, Reis ES, Costa LCB, Alves PB, Niculan ES, Brant RS (2010). Organic fertilization on phytomass production and essential oil content and quality of oregano (Origanum vulgare L.) under protected cultivation. Revista Bras Plantas Med 12: 80-89

9. Efthimiadou A, Bilalis D, Karkanis A, Froud-Williams B (2010). Combined organic/inorganic fertilization enhances soil quality and increased yield, photosynthesis and sustainability of sweet maize crop. Aust J Crop Sci 4(9): 722-729.

10. Giovannetti M, Mosse B (1980). An evaluation of techniques for measuring vesicular-arbuscular mycorrhizal infection in roots. New Phytol 84: 489-500.

11. Karkanis A, Bilalis D, Efthimiadou A (2011). Cultivation of milk thistle (Silybum marianum L. Gaertn.), a medicinal weed. Ind Crops Prod 34(1): 825-830.

12. Kayikcioglu HH (2013). Effects of composts from agroindustrial wastes on microbial activity of a typic Xerofluvent soil under Mediterranean conditions, SE Turkey. Geomicrobiol J 30: 228-236.

13. Khalil MY, Moustafa AA, Naguib NY (2007). Growth, phenolic compounds and antioxidant activity of some medicinal plants grown under organic farming condition. World J Agric Sci 3(4): 451-457.

14. Khaosaad T, Vierheilig H, Nell M, Zitterl-Eglseer K, Novak J (2006). Arbuscular mycorrhiza alter the concentration of essential oils in oregano (Origanum sp., Lamiaceae). Mycorrhiza 16: 443-446.

15. Kouřimská L, Sabolová $M$, Dvořáková $B$, Roubíčková $I$, Pánek J, Nový P (2014). Antioxidant activity of Lamiaceae herbs grown under organic and conventional farming. Sci Agric Bohem, 45: 19-25.

16. Mbatha AN, Ceronio GM, Coetzer GM (2014). Response of carrot (Daucus carota L.) yield and quality to organic fertiliser. South Afr J Plant Soil 31 (1): 1-6.

17. Mylavarapu RS, Zinati GM (2009). Improvement of soil properties using compost for optimum parsley production in sandy soils. Sci Hortic 120: 426-430.

18. Olmedo R, Nepote V, Grosso NR (2014). Antioxidant activity of fractions from oregano essential oils obtained by molecular distillation. Food Chem 156: 212-219.

19. Phillips JM, Hayman DS (1970). Improved procedures for clearing roots and staining parasitic and vesiculararbuscular mycorrhizal fungi for rapid assessment of infection. Trans Br Mycol Soc 55: 157-161.

20. Sotiropoulou DE, Karamanos AJ (2010). Field studies of nitrogen application on growth and yield of Greek oregano (Origanum vulgare ssp. hirtum (Link) Ietswaart). Ind Crops Prod 32(3): 450-457.

21. Singh, K., Chand K, Yaseen M (2014). Integrated nutrient management in Indian basil (Ocimum basilicum). Ind Crops Prod 55: 225-229.

22. StatSoft Inc. (2007). STATISTICA (data analysis software system), version 8.0. www.statsoft.com.

23. Vitoratos A, Bilalis D, Karkanis A, Efthimiadou A (2013). Antifungal activity of plant essential oils against Botrytis cinerea, Penicillium italicum and Penicillium digitatum. Not Bot Horti Agrobo 41: 86-92.

24. Wakley A, Black IA (1934). An examination of the Degtiareff methods for determining soil organic and proposed modification of chromic acid titration method. Soil Sci 37: 29-38.

25. Zhang X, Cao Y, Tian Y, Li J (2014). Short-term compost application increases rhizosphere soil carbon mineralization and stimulates root growth in long-term continuously cropped cucumber. Sci Hortic 175: 269-277. 